\title{
Forage crops, their place in reducing the costs of raising emu
}

\author{
I.L. GRAY ${ }^{1,3}$, A.W. GODDING ${ }^{1}$, C.A. GODDING ${ }^{1}$, L.F. GRAY ${ }^{1}$, L. HANCOX ${ }^{1}$, J.R. SAVILL ${ }^{1}$, \\ F.M. SAVILL ${ }^{1}$, D.L. HURNDELL ${ }^{1}$ and D.E. HUME ${ }^{2}$ \\ ${ }^{1}$ Counties Emu Growers, c/- I. Gray, 107 Avon Road, RD 1, Pokeno \\ ${ }^{2}$ AgResearch, Private Bag 11008, Palmerston North 5301 \\ ${ }^{3}$ lesian@ps.gen.nz
}

\section{Abstract}

Over the past 5 years, the emu industry has had forced upon it the need to adjust its practices to conditions determined by the meat, oil and hide markets, rather than the inflated prices enjoyed in the honeymoon years when emu breeders were exploiting a highly inflated bird market. The cost of economically raising birds to the slaughter stage is now the major challenge. The use of a forage crop to reduce feeding costs, the single largest cost to raising emu, was trialled in the Franklin County through funding from AGMARDT. Chicory, plantain, white and red clover were sown and rotationally grazed by emu. Emu on this forage crop also received a half ration of grain-based meal pellets (Forage-birds). This was compared with grazing emu on existing pasture and a full ration of meal pellets (Control-birds). The estimated savings per bird averaged $\$ 35.50$ (excl. GST), or $24 \%$, for the Forage-birds. For two of the three farms, the average saving per bird exceeded $\$ 44.00$ or $30 \%$, owing to lower costs of establishment for the forage crop and less extra meal feeding during summer/autumn drought and winter cold. Costs were recalculated to allow for economies of scale, and average savings then increased to $34 \%$. It is expected that greater savings, $40 \%$ or more, may be achieved through better preparation of the seedbed giving a better establishment of the sown forage species, if more favourable weather conditions prevail when the species are establishing, and through greater experience. However, it requires more land per bird and more watchful management in terms of seasonal change affecting the crop.

Meat quality ratings were all within acceptable levels, while fat from Forage-birds was yellow and Control-birds white. There were indications that fat from Forage-birds was healthier for humans through a better linoleic:linolenic fatty acid ratio and a better polyunsaturated:saturated fatty acid ratio than fat from Control-birds. At slaughter, differences in liveweight and meat quality between farms, and between birds, indicated the importance of correct slaughter and transport procedures to minimise stress. Birds from the forage group were more placid.

Keywords: chicory, Cichorum intybus, clover, cost:benefit, Dromaius novaehollandiae, emu, fat, Plantago lanceolota, plantain, Trifolium pratense, Trifolium repens

\section{Introduction}

Currently (1999/2000) the emu (Dromaius novaehollandiae) industry in New Zealand is at a transition stage. During the past decade, which saw the introduction of this ratite species as a promising farming possibility, those who acquired birds paid extremely high prices for them as breeders (Anon. 1999). The cost of feed was rather insignificant when compared with the value of the bird. Today the scene is much more pragmatic. The bird population is in the thousands but the markets for the meat, oil and leather are embryonic. The major challenge facing emu owners is the development of a reliable, consistent and viable outlet for these products. The development of markets is highly dependent on the farm-gate cost of the product. Farmers who wish to persist within the industry are searching for ways to reduce costs.

To raise a bird through to 14 months and $40 \mathrm{~kg}$ incurs costs from $\$ 266$ to $\$ 306$ per bird using the traditional practice of feeding processed grain to birds in captivity. With current returns (1999) for meat, fat and hide of $\$ 229$, reductions in costs of production are essential. In the Auckland Province, grain-based feed costs are the single greatest expense for the emu farmer representing $50 \%$ of the total costs, so determining the most economic feed practices is the top priority and so the prime reason for this study.

\section{Feeding the emu with forage}

Emus are classified as opportunistic feeders, and in the wild prefer fruits, seeds, flowers, insects and young forages (Angel 1996). Emus may eat some grass in the wild but it never forms the main part of their diet (Minnaar \& Minnaar 1992). This contrasts with other ratites such as ostriches and rheas that are adaptable grazers/browsers which in the wild eat mainly grasses 
and new leaves of shrubs and trees (Angel 1996). Emus and ostriches are both able to utilise substantial amounts of dietary forage, but have contrasting gastrointestinal tracts. Emus have a relatively long small intestine and short large intestine, while the opposite is true for ostriches. Ostriches can digest up to $60 \%$ of dietary fibre and emus up to $45 \%$, with $20 \%$ being an average amount digested by emu.

Research into emu husbandry is very limited, with only two systematic studies comparing forages with grain-based diets (Minnaar 1998). One study was carried out on Murray Goss's property at Feilding (Bassett \& Potter 1997), where chicory/white clover offered definite advantages over grain, with estimated savings of $\$ 38.71$ per bird. However, the study was only over 3 months when chicory grew well and one of the recommendations of the report was for a full 12 month trial. A similar trial in Tasmania (Nicholls 1997) concluded that while rape was unsuitable, chicory, kale and white clover may be valuable forage species. A cost saving of \$A27 was achieved per bird, a $17 \%$ saving over using grain-based feed, and with improved management and more favourable seasons it was considered that up to $\$ A 60$ could be saved.

A trial in the Franklin County to test different options of pasture and or forage as economic substitutes for bought-in meal was progressed by 4 members of the Counties Emu Association through funding from a "Progressive Farming Grant" from the Agricultural and Marketing Research and Development Trust (AGMARDT). This was approved in September 1999, and reported to AGMARDT by Godding et al. (2001).

\section{Trial objectives}

1. To determine the profitability of taking 3-monthold emu chicks through to 14 months of age and 40 $\mathrm{kg}$ killing weights by

- grazing on a forage containing chicory/plantain/ clover plus half ration of meal pellets (termed "Forage-birds"), compared with

- grazing on standard pasture and a full meal ration (termed "Control-birds"). Control-birds represented the traditional way that birds are fed and managed.

2. To determine whether Forage-fed birds grow at the same rate as Control-birds.

3. To explore bird handling techniques aimed at minimising stress to birds and so maximising the value of meat and hide.

It is important to note that the trial did not seek to determine the faster weight-gain feeding programme. It set precise feeding rates to test the relative profitability of two feeding programmes. The findings from the trial may then be applied to other feeding regimes.

\section{The trial region}

This trial was sited on four farms (A, B, C, D) in the Franklin County some $50 \mathrm{~km}$ south of Auckland, a region with a mild humid climate. Maximum temperatures average $13^{\circ} \mathrm{C}$ in July to $24^{\circ} \mathrm{C}$ in February, with 1800-1900 hours of sunshine per year. Mean annual rainfall for the region ranges from $1140 \mathrm{~mm}$ to $1400 \mathrm{~mm}$, being well-distributed throughout the year. This favourable climate raised the possibility of growing pasture or forage crops throughout the year thus reducing the dependence on grain for feeding emu.

\section{Control-birds}

Based on a management regime typical of an emu farm, the 10 Control-birds were enclosed for the full period of the trial in one grassed enclosure of 0.1 ha $\left(100 \mathrm{~m}^{2}\right.$ per bird). Farm $\mathrm{D}$ was smaller and could only run eight birds. For Farms A and B, this was an area previously used for emu with the pasture mainly consisting of ryegrass with almost a complete absence of flat weeds and clovers that are preferred by emu. Nutrition for the birds on these farms was almost entirely from the meal pellets. On Farm A, grass was mown as growth dictated, to encourage short, fresh and nutritious growth. In contrast, at Farm B by June 2000 the pen was overgrazed with $50 \%$ of the area as bare ground.

Pastures on Farms C and D were considered to be relatively nutritious for emu. On Farm C the enclosed area had never been grazed by emu but by sheep and cattle. The pasture consisted of a range of grasses including timothy, browntop, Paspalum, ryegrass (95\% infected with endophyte, Neotyphodium lolii), and a wide range of broad-leaved plants including dandelion, hawkbit and wild plantain. After 2 months of grazing, there was little evidence of grass seedheads or the broad-leaved plants. The birds obviously favoured these species over the grasses. Sheep were used periodically to eat the excess grass. Pasture on Farm D was wellgrassed, predominantly ryegrass with a noticeable presence of clover but few flat weeds. Mowing was used periodically.

\section{Forage-birds}

The forage crops were established in 0.2 ha areas, divided in half so that the crops could be rotationally grazed by the 10 birds of each of the Forage groups ( $200 \mathrm{~m}^{2}$ per bird). This meant the forage option required twice as much land as did the Control group. These 
areas were divided in halves, so that one half could be free of birds and so allow the crop to freshen and grow. This rotational grazing varied between farms and seasons, but generally the birds were moved every $7-$ 10 days.

The selection of legume and herb plants for the forage crop sought to develop a pasture mix that was nutritious, productive and persistent. Legumes selected were (with sowing rates) "Grasslands Sustain" white clover (Trifolium repens) $(4 \mathrm{~kg} / \mathrm{ha})$ and "Grasslands G27" red clover (Trifolium pratense) $(7 \mathrm{~kg} / \mathrm{ha})$. The herbs selected were "Grasslands Puna" chicory (Cichorum intybus) (6 kg/ha) and "Ceres Tonic" plantain (Plantago lanceolota) $(5 \mathrm{~kg} / \mathrm{ha})$.

\section{Forage establishment}

Soil samples were taken prior to establishing the forage crop on each farm, to determine the soil fertility and indicate the required fertiliser regime to correct any deficiencies. All farms broadcast-sowed their forage crops in October 1999 using similar seedbed preparation procedures. A glyphosate herbicide was used to kill the existing pasture and then the soil was cultivated (rotary-hoeing and/or discs, and rolling) to prepare the seed bed for sowing. Farmer $\mathrm{C}$ had sprayed an area with glyphosate and cultivated it in April 1999. After a period of fallow, secondary weed growth was again sprayed with glyphosate. This resulted in a very clean vigorous crop but meant that the land was not available for grazing for a longer period. Farm D did not have sufficient area to establish a forage crop.

\section{Meal pellets and feeding rates}

For the trial, all farms fed a proprietary brand (PCL Emu Feeds) to ensure a consistent quality. Chick Meal Pellets were fed from 3-9 months of age and Maintenance Meal Pellets from 10 months through to slaughter (Table 1). Control-birds were fed at the recommended rate of $100 \mathrm{~g} /$ day times age in months up to a maximum of $1 \mathrm{~kg}$ per day e.g., at 6 months of age, the birds were fed $600 \mathrm{~g}$ per day and from 10 months and older, $1 \mathrm{~kg}$ per day. Forage-birds were fed half the meal ration unless forage crop growth or bird weights slowed in which case the meal ration was increased and these extra amounts recorded.

\section{Bird allocation, handling and weighing}

The bird population was randomly allocated to the four farms. The first weighings took place on 13 December 1999 in a subdued-light environment of a darkroom $(3.5 \mathrm{~m} \times 3.5 \mathrm{~m})$ and weighing race built on each farm. Birds were ranked by order of weight and then each bird drafted alternately, into either the forage group or the control group. As a result, the average weights of birds in each group on each farm were not significantly different $(\mathrm{P}<0.01)$. Birds were then weighed monthly through to the trial's final weighing on 4 December 2000. Immediately after each weighing, decisions were made on feed management with the intention of keeping the group average bird weight as similar as possible on each farm.

\section{Slaughter procedure and analysis of meat and fat}

Owing to an abattoir closure, only one bird from each group for each farm was slaughtered on 11 December 2000 , that bird being the closest in weight to the average weight for that group. Birds were killed in the traditional manner - stunned with a blow to the head and then the throat severed. The slaughter was conducted on Farm $\mathrm{C}$, with birds being transported from the other farms. Each carcass (body minus the fat, shanks, head, intestines, skin, feathers) was weighed and placed in a chill chamber until it was deboned the following day. A $200 \mathrm{~g}$ sample of meat from each bird, the internal fillet between the hip joint and the backbone, was despatched for analysis. The carcass fat was weighed, rapidly frozen and transported for processing and analysis. For each group, only one bulked fat sample was analysed. Birds were also scored for fibre in the gizzard (score of $10=$ heavy amount of herbage fibre, $0=$ indicates no fibre present).

\section{Results}

\section{Management and emu growth rates}

Control-birds

Over the four farms, average weights of Control-birds were within $3 \mathrm{~kg}$ of the targeted $40 \mathrm{~kg}$ at the trial's completion in December 2000.

Table $₫ 1$ Nutrient specifications of meal pellets fed to emus in a feeding trial.

\begin{tabular}{|c|c|c|c|c|c|c|}
\hline Meal pellet type & $\begin{array}{c}\text { AME } \\
\mathrm{MJ} / \mathrm{kg} \text { DM }\end{array}$ & $\begin{array}{c}\text { Protein } \\
\min \%\end{array}$ & $\begin{array}{l}\text { Calcium } \\
\min \%\end{array}$ & $\begin{array}{c}\text { Phosphorus } \\
\max \%\end{array}$ & $\begin{array}{c}\text { Fibre } \\
\max \%\end{array}$ & $\begin{array}{c}\text { Salt } \\
\max \%\end{array}$ \\
\hline Chick meal (3-9 months) & 11.6 & 17.0 & 1.3 & 0.9 & 5.5 & 0.4 \\
\hline Maintenance meal (10-14 months) & 10.9 & 12.0 & 0.85 & 0.5 & 8.0 & 0.3 \\
\hline
\end{tabular}




\section{Forage-birds}

Initial establishment of the crops was good in all cases. However all crops became invaded, to varying degrees, with various weeds and or grasses, with species differing for each farm. Mowing or grazing was used to control extra growth, not so much for the chicory and plantain, but for the invading weeds and grasses that were unpalatable to emu. Some of this invasion could be attributed to the pre-sowing period which should have been longer, allowing for the germination of weed and grass seed dormant in the soil and then elimination by a second herbicide spraying prior to cultivation, as done on Farm C. Invasion also occurred as a severe drought in February/March 2000 weakened the young forage species that presumably were still establishing deep roots e.g., chicory. Invasion occurred in winter as forage growth rates were low owing to the cool winter temperatures. This was particularly so on Farm B as the forage area was on a soil that was winter wet, and invading grasses were not well controlled.

Extra meal was therefore required at the times of drought and winter cool, depending on the conditions on each farm, to maintain similar emu growth rates for the two groups. Farm $\mathrm{C}$ removed birds from the forage crop for two periods and fed them a full meal ration. During late autumn, it was noticed on Farm B that birds were not grazing despite the recovery of the pasture. The meal was reduced to $50 \%$ and the birds promptly started to graze the pasture.

At the final weighing on 4 December 2000, the average Forage-bird weighed less than the average Control- bird by $1.2 \mathrm{~kg}, 4.2 \mathrm{~kg}$ and $2.6 \mathrm{~kg}$ for Farms A, $\mathrm{B}$ and $\mathrm{C}$, respectively. Only for Farm B was this difference statistically significant $(\mathrm{P}=0.048)$.

\section{Comparison of feed costs}

The meal cost for each bird in any one of the four control groups was $\$ 146.35$ for the trial period only (all costs exclude GST). This does not include any costs of raising chicks to 3 months of age. The trial programme required the Forage-birds to be fed half the ration of meal (\$73.17 per bird). The severe summer/autumn drought, and winter cold, both affected the forage crops and all three farms had to take corrective measures by feeding extra meal (Table 2). For each farm, costs for the forage crop were calculated from costs of establishment, fertiliser and seed, and then spread over the estimated life of the forage crop (Table 2).

Savings from forage grazing over full meal feeding averaged $24 \%$ (Table 2), with the lowest savings occurring on Farm B owing to the highest establishment costs and extra meal requirements. These calculations do not allow for costs of extra land and fencing required for the forage crop, or benefits of complementary grazing with sheep and or cattle in order to utilise (control) grasses and extra forage growth rather than mowing. Given more experience and a more typical summer/ autumn rainfall, triallists believe savings could be in the order of $40 \%$.

Table 22 Actual component and total costs for Forage-birds, savings per bird (compared with Control-birds) and expected forage life in an emu feeding trial. Meal cost for Control-birds was $\$ 146.35$ per bird. (Costs exclude GST).

\begin{tabular}{|c|c|c|c|c|}
\hline & \multicolumn{3}{|c|}{------------- Farm ------------- } & \multirow[b]{2}{*}{ Average } \\
\hline & A & B & C & \\
\hline Basic meal $(\$)$ & 73.17 & 73.17 & 73.17 & 73.17 \\
\hline Extra meal (\$) & 10.99 & 27.08 & 15.71 & 17.92 \\
\hline $\begin{array}{l}\text { Forage crop } \\
\text { establishment for }\end{array}$ & & & & \\
\hline $\begin{array}{l}0.2 \text { ha }(\$) \\
\text { Expected life of forage }\end{array}$ & 361.51 & 557.55 & 400.00 & 418.95 \\
\hline crop (years) & 2 & 2 & 3 & \\
\hline $\begin{array}{l}\text { Forage crop cost } \\
(\$ \text { per bird })\end{array}$ & 18.07 & 27.88 & 13.33 & 19.76 \\
\hline Total cost $(\$)$ & 102.23 & 128.13 & 102.21 & 110.85 \\
\hline Savings (\$) & $\begin{array}{l}44.12 \\
30 \%\end{array}$ & $\begin{array}{l}18.22 \\
12 \%\end{array}$ & $\begin{array}{l}44.14 \\
30 \%\end{array}$ & $\begin{array}{l}35.50 \\
24 \%\end{array}$ \\
\hline
\end{tabular}

Costs of establishing the forage crop were higher (average $\$ 2095 /$ ha) than those reported by others e.g., \$561/ha (Stevens et al. 2000), \$910/ha (McGrath et al. 1998). In part, this was owing to the small area ( 0.2 ha per farm) that was established on each farm. Costs were recalculated for each farm using the Lincoln University Financial Budget Manual (Burtt 1999) to represent costs savings that can be made with establishment of larger areas. To improve the establishment success of the sown species and longevity of the crop (estimated 3 years), costs were based on

1. drilling into a fully cultivated seed bed

2. using two applications of glyphosate herbicide to remove unwanted resident plant species, and

3. reduced sowing rates owing to the higher establishment success of drilled seed (white clover $3 \mathrm{~kg} / \mathrm{ha}$, red clover $6 \mathrm{~kg} / \mathrm{ha}$, chicory $4 \mathrm{~kg} / \mathrm{ha}$, plantain $2 \mathrm{~kg} / \mathrm{ha})$.

Establishment costs, including a soil test, would have been $\$ 611 /$ ha for a larger area. In addition, each farm required different fertiliser applications (Table 3). The resulting costs for establishing the forage crops on larger areas of each farm (average $\$ 5.76$ per bird) were approximately $30 \%$ of the costs of the 0.2 -ha paddocks on the trial farms ( $\$ 19.76$ per bird). The forage crop represented $6 \%$ of the total costs of raising forage-fed birds while on the smaller scale this was $18 \%$ of the 
total costs. Savings per bird of using forage were increased from an average of $24 \%$ to $34 \%$ (Table 3 ).

Table $₫ 3$ Calculated component and total costs for Forage-birds, savings per bird (compared with Control-birds) and expected forage life using values from Table 2 but incorporating economies of scale from establishing larger areas (Burtt 1999). Meal cost for Control-birds was $\$ 146.35$ per bird. (Costs exclude GST).

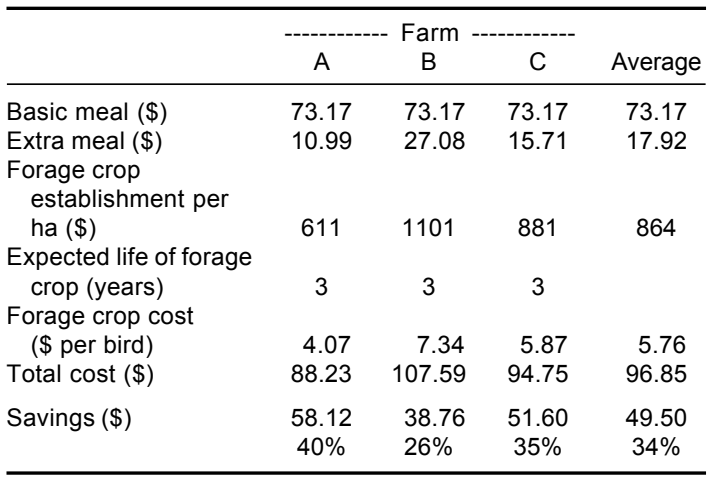

\section{Products - meat and fat}

\section{Yield of product}

The slaughtered Forage- and Control-birds differed little $(\mathrm{P}>0.05)$ in liveweight (average $35.7 \mathrm{~kg}$ ), weight of fat (average $6.6 \mathrm{~kg}$ ), weight of carcass (average $19.4 \mathrm{~kg}$ ), product yield (average 68\%), while average gizzard fibre score was higher for Forage-birds (8.0 and 4.7, respectively) $(\mathrm{P}<0.05)$ consistent with the foraging they did on the crop. All birds that were transported to Farm $\mathrm{C}$ for slaughter lost an estimated $4.5 \mathrm{~kg}$ liveweight (Godding et al. 2001), compared with the birds from Farm $\mathrm{C}$ that were not transported prior to slaughter. This difference could not be attributed to gut fill as all birds were off feed for the same period of time. This liveweight difference however did not reflect in weight of product (fat and carcass). With none of the other five birds travelling more than $30 \mathrm{~km}$ and in a darkened trailer for no more than 4 hours before slaughter, this apparent transport effect raises an important issue. Options to manage this effect must be considered by the emu industry.

\section{Meat quality}

Tenderometer readings (average $6.6 \mathrm{~kg}$ ), relative water holding capacity (average 0.23 ) and $\mathrm{pH}$ (average 5.67) were within the acceptable standards for beef and lamb. Two Foragebirds had more stressful deaths than the others, which corresponded with higher tenderometer ratings (average $8.33 \mathrm{~kg}$ ) than the other five birds (average $5.95 \mathrm{~kg}$ ).
Similar effects were also apparent for relative water holding capacity. This resulted in an overall higher average for Forage-birds (7.6 vs. 5.9) $(\mathrm{P}<0.05)$. This immediately-prior-to-death trauma has significance to the efficiency of slaughtering methods within the emu industry.

\section{Body and gut fat}

The yields of oil from Forage- and Control-birds were both just under $80 \%$. This is a good return as returns can be as low as $65 \%$. At slaughter, it was immediately obvious that the fat from Forage-birds was a yellow colour while the Control-birds had much whiter fat. This is a consistent result where an animal's diet has a high proportion of plant fodder containing high concentrations of $\beta$-carotenes, xanthophylls and other colouring compounds.

There were differences in the fatty acid composition of the fat (Table 4). Oleic acid (the principal fatty acid in olive oil) levels were over $50 \%$ in both groups. The 18:2 and 18:3 fatty acids (linoleic, one of the "omega6 " fatty acids, and linolenic, one of the "omega-3" fatty acids, respectively) were higher in Forage-birds. The omega-6:omega-3 ratio, or linoleic:linolenic ratio (which in Western human diets is presently $20: 1$ to $30: 1$ and is recommended to be $1: 1$ or at the most $4: 1$ in the diet) was 2.93 for Forage-birds and 19.5 for Control-birds. For Control-birds, this is within the range reported by Minnaar (1998). The polyunsaturated:saturated fatty acid ratio for both groups was above the 0.45 "desired minimum" for a human diet, but Forage-birds' ratio (0.79) was higher than the Control-birds' (0.47). Although the number of samples analysed was limited to one per group, these results indicate that fat from Forage-birds may be healthier overall for humans than fat from Control-birds.

Table $\llbracket 4$ Composition of fat ( $\mathrm{g} / 100 \mathrm{~g})$ for Forage- and Control-birds in an emu feeding trial.

\begin{tabular}{|c|c|c|c|c|}
\hline $\begin{array}{l}\text { Fatty acid profile } \\
\text { Carbon atoms:double bonds } \\
\text { (common name) }\end{array}$ & Forage $^{1}$ & Control $^{2}$ & $\mathrm{NZ}$ range $^{3}$ & $\begin{array}{l}\text { American Emu } \\
\text { Association } \\
\text { range }^{4}\end{array}$ \\
\hline 18:1 (Oleic) & 53.5 & 52.8 & $35.6-49.8$ & $38.4-56.4$ \\
\hline 18:2 (Linoleic) & 13.2 & 11.7 & $4.8-21$ & $6.2-24.2$ \\
\hline 18:3 (Linolenic) & 4.5 & 0.6 & $<0.1-11$ & $0.1-1.8$ \\
\hline \multicolumn{5}{|c|}{ One measurement on a bulked sample from three birds } \\
\hline \multicolumn{5}{|c|}{ One measurement on a bulked sample from four birds } \\
\hline \multicolumn{5}{|c|}{ Data supplied by Fostech, Nelson } \\
\hline $4 \quad$ Minnaar (1998) & & & & \\
\hline
\end{tabular}

\section{Summary of results}

- Raising emu using the "forage principle" increased profitability (savings), ranging from $13 \%$ to $30 \%$ 
(average 24\%), with savings of $40 \%$ or more achievable in this region with more experience. With economies of scale from sowing larger areas, savings may average $34 \%$.

- Establishment of the forage crop requires good primary weed control and appropriate sowing equipment to ensure the greatest crop vigour and longevity.

- Control of excess plant growth in both feeding systems is needed. This would be best achieved by complementary grazing with sheep, deer or cattle.

- Under the trial conditions, a half-meal ration fed to Forage-birds was not sufficient to maintain bird growth rates compared to a full meal ration fed to Control-birds on standard pasture. Extra meal was required when growth of forage species slowed owing to drought and cool winter temperatures.

- Regular weighing of birds allowed early correction of reduced weight-gain on forage. Careful monitoring of the forage crop could probably achieve the same result coupled with the practice of putting out, morning and afternoon, only enough meal for the birds to consume in half-an-hour.

- Fat from Forage-birds was yellow and Controlbirds white. The composition of the fat from Foragebirds may be healthier for humans through a better linoleic:linolenic fatty acid ratio and a better polyunsaturated:saturated fatty acid ratio. Forage feeding did not affect meat quality or yield.

- Forage-birds were quieter and easier to handle.

- Minimal stress during handling and transport is important to optimise meat and hide quality, and maintain liveweight. Darkrooms were essential for pacifying the birds during handling.

\section{ACKNOWLEDGEMENTS}

Numerous sources of information and encouragement were offered throughout the 15 months of the trial, in particular members of the Counties Emu Branch of the New Zealand Emu Farmers Association, and Ivan and Poula Pat, Harewood Emu-Ostrich Farm, Christchurch.

We also thank Ross Davies and staff of the Institute of Technology and Engineering, Massey University for meat testing, and to Mike Foster, Fostech, for fat and oil testing. Finally, the trial team acknowledges with thanks, the readiness of the AGMARDT Trustees to risk approving a grant for this purpose.

\section{REFERENCES}

Angel, C.R. 1996. A review of ratite nutrition. Animal Feed Science Technology 60: 241-246.

Anon. 1999. Financial Budget Manual 1999. Farm Management Group, Lincoln University, Lincoln.

Bassett, S.M.; Potter, M.A. 1997. Emu Chicory Feed Experiment. Final Report to New Zealand Emu Ltd. $18 \mathrm{pp}$.

Burtt, E.S. (Ed.). 1999. Financial budget manual 1999. Lincoln University, Canterbury.

Godding, T.; Godding, C.; Gray, I.; Gray, L.; Hancox, L.; Savill, J.; Savill, F.; Hurndell, D. 2001. Counties Emu Forage Trial. Report to the Agricultural and Marketing Research and Development Trust. AGMARDT, Wellington. 25 pp.

McGrath, D.F.; Dawson, J.E.; Thomson, N.A.; Simons, H.P. 1998. More summer milk - the opportunities identified. Proceedings 50th Ruakura Farmers' Conference: 85-94.

Minnaar, M. 1998. The Emu Farmer's Handbook Volume 2. Commercial Farming Methods For Emus, Ostriches and Rheas. Nyoni Publishing Co., Groveton, Texas. 320 pp.

Minnaar, P.; Minnaar, M. 1992. The Emu Farmer's Handbook. Induna Company, Groveton, Texas. 178 pp.

Nicholls, J. 1997. Investigation of growth rate and cost factors affecting commercial emu rearing using cool climate forage based production systems. RIRDC Project No. N.A.P.-15. Australian Rural Industries Research and Development Corporation, Barton, ACT. 34 pp.

Stevens, D.R.; Gibson, A.K.; Casey, M.J. 2000. Improving on-farm profitability of sheep and deer systems using pasture renewal in the southern South Island. Proceedings of the New Zealand Grassland Association 62: 201-205. 